PETIR: Jurnal Pengkajian dan Penerapan Teknik Informatika Vol. 13, No. 1, Maret 2020, P-ISSN 1978-9262, E-ISSN 2655-5018 DOI: https://doi.org/10.33322/petir.v13i1.869

\title{
Penentuan Rute Pengiriman Barang Dengan Metode Nearest Neighbor
}

\author{
Sandi Martono ${ }^{1}$; Harco Leslie Hendric Spits Warnars $^{2}$ \\ ${ }^{1}$ Departemen IT, PT Sumber Alfaria Trijaya Tbk. \\ ${ }^{2}$ Computer Science Department, BINUS Graduate Program - Doctor of Computer Science, \\ Bina Nusantara University, Jakarta, Indonesia 11480 \\ ${ }^{1}$ sandi.martono@gmail.com \\ ${ }^{2}$ spits.hendric@binus.ac.id
}

\begin{abstract}
The faster the goods are sent to consumers, the easier to get items and company profit increase. The distribution produces one of the problem solutions in finding a route by minimizing the distance from the warehouse to the store and having a different number of requests for items. The writers are using the nearest neighbor method to complete the determination of the distribution route of items from the warehouse to the store, to reduce the total delivery distance, time and cost burden that is burdened to the company. The search results using the Nearest Neighbour method produces the fewest number of routes compared to the procedure before using the method and the total distance using the method 98,610 meters or $98.61 \mathrm{~km}$ whereas before using the method was 124,198 meters or $124.198 \mathrm{~km}$. Thus, there is a reduction in the distance of 25,588 meters or $25.588 \mathrm{~km}$ which amounted to $20.6026 \%$.
\end{abstract}

Keywords: delivery of goods, nearest neighbor, route search

\begin{abstract}
ABSTRAK
Semakin cepat barang sampai ke konsumen maka menjadi lebih mudah untuk mendapatkan barang dan keuntungan perusahaan semakin bertambah. Pada pendistribusian membentuk salah satu pemecahan masalah untuk mencari rute dengan meminimumkan jarak dari lokasi gudang ke toko dan memiliki jumlah permintaan barang yang berbeda-beda. Menggunakan metode nearest neighbor untuk menyelesaikan penentuan rute distribusi barang dari gudang ke toko, dengan tujuan mengurangi total jarak pengiriman, waktu dan beban biaya yang dibebani perusahaan. Hasil pencarian rute menggunakan metode nearest neighbor menghasilkan jumlah rute paling sedikit dibandingkan dengan sebelum menggunakan metode dan pada total jarak dengan menggunakan metode 98610 meter atau 98,61 km sedangkan jika pada rute sebelum mengunakan metode 124198 meter atau 124,198 km terjadi pengurangan jarak 25588 atau 25,588 atau sebesar $20.6026 \%$.
\end{abstract}

Kata kunci: pengiriman barang, nearest neighbor, pencarian rute 
PETIR: Jurnal Pengkajian dan Penerapan Teknik Informatika Vol. 13, No. 1, Maret 2020, P-ISSN 1978-9262, E-ISSN 2655-5018 DOI: https://doi.org/10.33322/petir.v13i1.869

\section{PENDAHULUAN}

Kemudahan untuk membeli barang di pasar dengan mudah disebabkan karena pendistribusian barang semakin cepat dan mudah. Semakin cepat barang sampai ke konsumen maka konsumen menjadi lebih mudah untuk mendapatkan barang dan keuntungan perusahaan semakin bertambah. Seiring perkembangan jumlah rute jalan semakin bertambah dan menjadi rumit jika jumlah pengiriman tujuan barang semakin banyak sedangkan jumlah kendaraan pada saat pendistribusian sangat sedikit [1].

Pertumbuhan ekonomi yang selalu meningkat setiap tahunnya akan selalu berdampingan dengan pendistribusian. Kondisi ini menyumbang pemakaian energi yang berdampak juga terhadap emisi gas buang dari kendaraan[2]. Saat ini, secara luas diketahui bahwa persentase penting dari biaya akhir suatu produk terkait dengan pergerakan, sehingga upaya untuk mengurangi biaya ini sangat penting dalam dunia globalisasi [3]. Selain mengurangi biaya pada pendistribusian.

Perencanaan urut-urutan rute pendistribusian produk dari gudang sampai dengan ke toko masih mengandalkan pengalaman dan keputusan subyektif sehingga sulit untuk memperhitungkan pembiayaan pada pendistribusian barang ke toko sebagai pelanggan. Keputusan yang subyektif di perlukan pengalam dalam pengambilan keputusan dalam pencarian jarak terdekat sehingga perusahaan akan sangat ketergantungan terhadap seseorang yang melakukan penentuan rute dan jika penentuan rute tidak dilakukan dengan maka keterlambatan barang pada pengiriman dan penerunan penjualan barang ke konsumen. PT Sumber Alfaria Trijaya Tbk. merupakan perusahaan ritel dengan melayani penjualan barang kebutuhan sehari-hari dan memiliki banyak konsumen. Perusahan retail sangat berkaitan erat dengan pendistribusian barang ke toko, sehingga menjadi salah satu perhatian khusus dikarenakan sangat berpengaruh terhadap penjualan memiliki efek positif dan signifikan terhadap kebahagiaan dan kepuasan pelanggan, khususnya di sektor ritel [4].

Kesulitan pada pendistribusian vehicle routing problem (vrp) membentuk salah satu pemecahan masalah untuk mencari rute dengan meminimumkan dari suatu gudang ke toko yang memiliki lokasi yang berbeda dengan jumlah permintaan yang berbeda-beda[5]. NN juga digunakan untuk permasalahan traveling salesman problem [6], efisiensi latensi [7] dan penentuan rute dari satu kota kemudian mendatangi kota lain[8]. Penyelesaian distribusi barang dalam penelitian ini menggunakan algoritma NN. Metode nearest neighbor adalah merancang rute perjalanan truk untuk melayani tempat penampungan sampah sementara terdekat dengan lokasi yang terakhir dikunjungi[9]. Nearest neighbor metode heuristik digunakan menjadi dasar penentuan rute bagi metode-metode metaheuristik dan digunakan untuk pemecahan masalah penentuan rute.

Pada sebelumnya juga menggunakan metode untuk penentuan rute yang membandingkan metode antara algoritma genetika dan perjalanan untuk menemukan jarak minimum dengan melintasi masing-masing set kota tertentu minimal sekali dan kemudian melintasi kembali ke mulai kota. Algoritma genetika 25 kota dengan jarak 42.2683 total waktu proses 0.8631 lalu pada pengujian 50 kota jarak yang dihasilkan 77.2339 waktu proses 6.6354 dan pada 100 kota jarak yang di dapat 86.4397 total waktu proses 2.9486 kemudian pengujian dengan algoritma nearest neighbor 25 kota dengan 41.3736 total waktu proses 12.5727 lalu pada pengujian 50 kota jarak yang dihasilkan 62.3458 waktu proses 14.5790 dan 100 kota dengan 82.9532 total waktu proses 21.1832 . Hasil dari penelitian tesebut bahwa algoritma nearest neighbor memiliki penyelesaian dalam perhitungan lebih cepat di bandingan dengan algoritma genetika [8].

Pendistribusian produk pada penelitian ini membahas tentang pendistribusian produk dengan menggunakan jalur darat merupakan distribusi dengan kendaraan pengangkut barang. Pendistribusian dari ke konsumen membutuhkan perencanaan yang akurat dan diperlukan pertimbangan terhadap rute yang digunakan sehingga didapatkan biaya transportasi dengan waktu 
PETIR: Jurnal Pengkajian dan Penerapan Teknik Informatika Vol. 13, No. 1, Maret 2020, P-ISSN 1978-9262, E-ISSN 2655-5018 DOI: https://doi.org/10.33322/petir.v13i1.869

yang efisien menggunakan algoritma nearest neighbor. Hasil dari penelitian tersebut yaitu pada armada 1 pada awal sebelum menggunakan metode armada pertama $508.4 \mathrm{~km}$, kedua $495,7 \mathrm{~km}$, ketiga 599,6 km, keempat 420,1 km setelah menggunakan metode nearest neighbor armada pertama $399,5 \mathrm{~km}$, kedua $377,7 \mathrm{~km}$, ketiga 469,7 km, keempat 238,7 km. Adapun penghematan jarak sebesar sebesar $26,59 \%$, pengurangan waktu pengurangan sebesar $19,07 \%$, lalu pada bahan bakar terdapat pengurangan sebesar $26,59 \%, 4,50 \%$ biaya yang dihemat pada sopir dan pendamping, dan Terakhir total biaya pendistribusian yang dihitung menjadi terjadi penghematan sebesar 25,71\% [10].

Penelitian lainnya yaitu penggunaan algoritma nearest neighbor untuk kendaraan listrik digunakan untuk optimasi jalur untuk pembangunan rute pada pengisian baterai. Parameter yang menjadi dasar pada penelitian tesebut diantaranya adalah debit baterai dan jarak antar kota. solusi berbasis nearest neighbor untuk masalah rute hemat energi untuk kendaraan listrik disajikan termasuk stasiun pengisian baterai. Hasil simulasi membuktikan keakuratan algoritma dalam menghasilkan solusi yang dioptimalkan pada kendaraan listrik untuk masalah rute dengan pengisian baterai. Algoritma berbasis nearest neighbor terbukti produktif, dinamis, dan ekonomis [11].

Kemudian pada penelitian selanjutnya mengunakan metode nearest neighbor merupakan salah satu algoritma heuristik yang telah terbukti merupakan teknik yang berhasil diterapkan pada sejumlah masalah optimasi kombinatorial. Algoritma penyisipan tetangga terdekat adalah salah satu metode komputasi yang efisien untuk masalah perutean kendaraan. Permasalahan rute dengan kapasitas pada kendaraan di perguruan tinggi. menggunakan halte sebagai titik pelanggan yang harus dilayani dengan jumlah total 20 dengan kapasitas siswa sebagai pelanggan yang harus dilayani kemudian jumlah kendaraan 4 unit. Hasil dari penggunaan metode dengan total jarak 593,262 dan menghasilkan 4 rute yang berbeda [12].

Dari penelitian terdahulu sehingga permasalahan pada penetuan rute untuk pengiriman barang pada PT Sumber Alfaria Trijaya Tbk. dengan menggunakan metode nearest neighbor untuk menyelesaikan penentuan rute distribusi barang dari gudang ke toko, dengan tujuan mengurangi total jarak pengiriman, waktu dan beban biaya yang dibebani perusahaan.

\section{METODE/PERANCANGAN PENELITIAN}

\subsection{Sumber Data}

Sumber data yang diperoleh pada penelitian ini ialah data permintaan barang di PT Sumber Alfaria Trijaya Tbk. Jumlah toko yang digunakan berjumlah 13 yang terdiri dari jumlah kubikasi yang berbeda pada setiap tokonya pada permintaan dalam satu hari. Jarak antar toko yang terdiri dari toko ke toko lain yang di dapat berdasarkan koordinat yang sudah berbentuk jarak dengan satuan meter. Kapasitas kubikasi kendaraan memiliki maksimum yang seragam dengan total $7746900 \mathrm{~cm}^{3}$.

Pada tabel 1 terlihat data permintaan barang yang harus dikirim dari gudang berjumlah 13 toko dengan jumlah permintaan yang berbeda-beda. Satuan kapasitas dari setiap permintaan barang menggunakan centimeter kubik. Kendaraan yang akan digunakan memiliki kapasitas maksimal $7746900 \mathrm{~cm}^{3}$.

Tabel 1. Permintaan barang dari toko

\begin{tabular}{|c|c|c|c|}
\hline No & Kode Toko & Nama Toko & Kubikasi $\left(\mathbf{c m}^{3}\right)$ \\
\hline 1 & A1 & TOKO 1 & 1682658 \\
\hline 2 & A2 & TOKO 2 & 1464162 \\
\hline 3 & A3 & TOKO 3 & 2483022 \\
\hline 4 & A4 & TOKO 4 & 2483022 \\
\hline 5 & A5 & TOKO 5 & 2243232 \\
\hline 6 & A6 & TOKO 6 & 1893731 \\
\hline
\end{tabular}


PETIR: Jurnal Pengkajian dan Penerapan Teknik Informatika Vol. 13, No. 1, Maret 2020, P-ISSN 1978-9262, E-ISSN 2655-5018 DOI: https://doi.org/10.33322/petir.v13i1.869

\begin{tabular}{|l|l|l|l|}
7 & A7 & TOKO 7 & 2243232 \\
\hline 8 & A8 & TOKO 8 & 2022624 \\
\hline 9 & A9 & TOKO 9 & 2490933 \\
\hline 10 & A10 & TOKO 10 & 1893731 \\
\hline 11 & A11 & TOKO 11 & 1522152 \\
\hline 12 & A12 & TOKO 12 & 2997580 \\
\hline 13 & A13 & TOKO 13 & 1433460 \\
\hline
\end{tabular}

Tabel 2. Hasil rute sebelum menggunakan metode NN

\begin{tabular}{|c|c|c|c|}
\hline No & Toko & Kubikasi $\left(\mathbf{c m}^{\mathbf{3}}\right)$ & Total Jarak (m) \\
\hline 1 & A1, A6 & 4443065 & 26455 \\
\hline 2 & A3, A5, A10 & 5612201 & 26346 \\
\hline 3 & A2, A4, A9 & 5670674 & 17749 \\
\hline 4 & A7, A12, A13 & 6674272 & 28926 \\
\hline 5 & A8, A11 & 3544776 & 24722 \\
\hline \multicolumn{2}{|l}{ Total Jarak } \\
\hline
\end{tabular}

Pada tabel 2 terdapat 5 rute pengiriman barang dari gudang sebelum menggunakan metode.

\subsection{Capacitated Vehicle Routing Problem (CVRP)}

Capacitated Vehicle Routing Problem (CVRP) merupakan perkembangan dari model vechicle routing problem (VRP). VRP diperkenalkan pada tahun 1959 oleh Dantzig dan Ramser untuk memecahkan masalah pengiriman bensin[13]. Sejak saat itu terdapat banyak varian dari model tersebut yang telah membuktikan hasil yang sangat memuaskan. Secara umum VRP di desain sebagai satu kesatuan dari rute untuk kendaraan dengan kondisi dimana toko atau lokasi pengiriman tepat di kunjungi satu kali dan semua rute dimulai dari gudang dan berakhir di gudang[14].

Penentuan rute pada penelitian ini menggunakan pemodelan dengan CVRP digunakan untuk penentuan pengoptimalan rute pada jarak tempuh perjalanan kendaraan dari gudang ke toko sejumlah permintaan toko sebagai pelanggan dari sehingga menghasilkan rute dengan jarak yang minimum. Pada kendaraan dikirim dari gudang untuk mengirimkan barang-barang yang dibutuhkan dan kembali ke gudang[11]. Setiap kendaraan dapat menempuh jarak total terbatas dengan kapasitas terbatas, hanya satu kendaraan pada satu waktu dapat melayani setiap pelanggan, sehingga semua tuntutan pelanggan terpenuhi.

\subsection{Nearest Neighbor}

Nearest neighbor metode heuristik yang digunakan untuk pemecahan masalah sebagai dasar untuk penentuan rute metode NN juga banyak digunakan. Algoritma heuristik yang memang berkinerja signifikan lebih baik dan realistis dalam pembentukan rute [15]. Untuk sejumlah kecil kota, masalah dapat dengan mudah dan cepat diselesaikan dengan algoritma nearest neighbor [16].

langkah pertama memasukkan tujuan ke dalam rute pengiriman, hal pertama yang harus dilakukan adalah mengurutkan nilai terkecil yang telah diperoleh mulai dari yang terbesar hingga yang terendah[17]. Pada komputasi NN memiliki kinerja yang sangat cepat[18]. NN ditemukan oleh Solomon pada tahun 1987 yang konsepnya adalah mengunjungi lokasi terdekat dari masing-masing lokasi yang sedang dikunjungi[19]. 

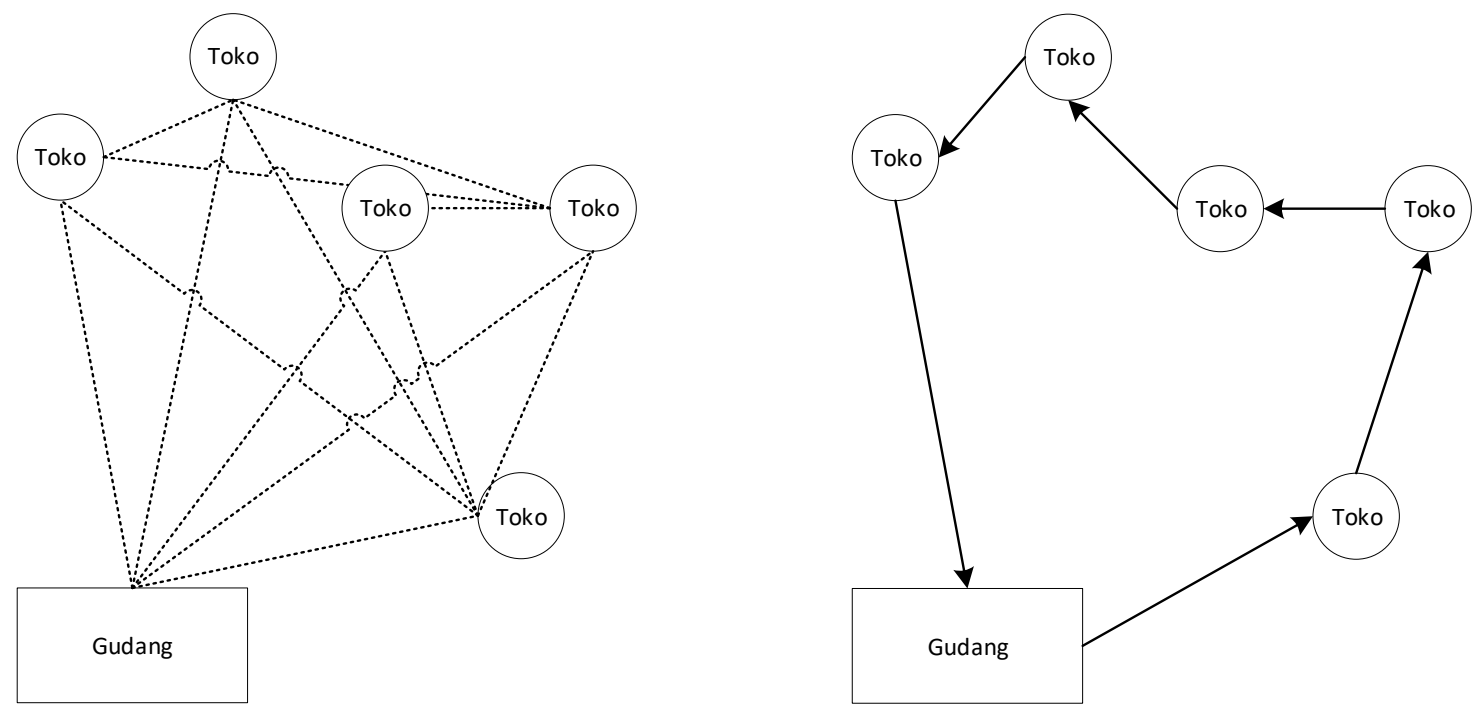

Gambar 1. Bentuk penentuan rute nearest neighbor

Pada gambar 1 merupakan penentuan rute dengan menggunakan metode nearest neighbor dengan mencari jarak terdekat dari lokasi gudang kemudian berpindah dari satu toko ke toko yang lain Berikut pemecahan masalah dengan pada pendistribusian menggunakan NN kumpulan dari perjalanan atau rute yang tersimpan dalam urutan adalah hasil dari algoritma ini[20]:

1. Dimulai dari gudang di setiap perjalanan atau rute pengiriman.

2. Mencari tujuan pengiriman barang yang belum dikunjungi dengan jarak yang paling terdekat dari lokasi awal dan tidak melebihi kapasitas kendaraan.

a. jika tujuan pengiriman barang terpilih dan masih memiliki sisa kapasitas maka kembali ke langkah 2 dan diubah sebagai lokasi awal.

b. jika kendaraan sudah tidak memiliki sisa kapasitas maka kembali ke langkah 1 buat perjalanan atau rute baru.

3. Jika semua tujuan pengiriman telah di kunjungi satu kali pada algoritma selesai.

\section{Hasil dan Pembahasan}

\subsection{Model Pencarian Rute pada PT Sumber Alfaria Trijaya Tbk.}

Permasalahan penentuan rute pada PT Sumber Alfaria Trijaya Tbk. di definisikan sebagai suatu graf $G=(V, E)$. Himpunan $\mathrm{V}$ terdiri dari atas gabungan himpunan toko $C$ dan gudang, $V=$ $\{0,1, \ldots, 14\}$. Himpunan $C$ berupa pelanggan 1 sampai dengan $13, C=\{1,2, \ldots, 13\}$ dan gudang dinyatakan dengan 0 dan 14. Semua penentuan rute dimulai dan berakhir di gudang. Anggota kendaraan melambangkan nilai $\mathrm{K}$ yang bersifat homogen dengan kapasitas sebagai $q$. Setiap toko $i$ memiliki permintaan barang untuk setiap $i \in C$ sehingga panjang perjalanan pada rute dibatasi oleh kapasitas kendaraan. Lalu persamaan himpunan $c i i=c j j=0$ untuk toko pasti memiliki jarak 0 jika toko awal dan akhir sama dan diperlakukan sama pada lokasi gudang. $X_{i j}$ bernilai 1 jika ada perjalanan dari toko i ke toko $\mathrm{j}$, sebaliknya jika nilainya 0 maka tidak terdapat perjalanan dari toko $\mathrm{i}$ ke toko j. Model matematika pada penelitian ini sebagai berikut:

Meminimumkan $Z=\sum_{i=0}^{13} \sum_{j=1}^{14} C_{i j} x_{i j}$ 
Dengan kendala,

1. Setiap toko didatangi tepat satu kali pada kendaraan.

$\sum_{j=1}^{14} x_{i j}=1, \quad \forall i \in V$

2. Total semua toko tidak melebihi kapasitas pada maksimal kendaraan.

$\sum_{i=0}^{13} d_{i} \sum_{j=1}^{14} x_{i j} \leq 7746900$,

3. Untuk setiap rute dimulai dari gudang.

$$
\sum_{j=1}^{z 14} x_{0 j}=1
$$

4. Setiap kendaraan yang mendatangi toko pasti akan meninggalkan toko.

$$
\sum_{i=0}^{13} x_{i j}-\sum_{j=1}^{14} x_{i j}=0
$$

5. Setiap perjalan rute berakhir di gudang.

$$
\sum_{i=0}^{13} x_{i 14=1}
$$

6. Variabel merupakan bilangan biner.

$$
x_{i j k} \in\{0,1\}, \forall i, j \in V, \forall k \in K
$$

Pada penelitian ini model pencarian rute yang digunakan pada PT Sumber Alfaria Trijaya Tbk. Asumsi pencarian rute uang di gunakan sebagai berikut:

1. Setiap permintaan barang dari toko dapat dipenuhi oleh gudang.

2. Jumlah toko(n) pada penelitian ini diketahui berjumlah 14 (13 toko dan 1 gudang).

3. Maksimal kendaraan memiliki kubikasi $7746900 \mathrm{~cm} 3$.

4. Maksimal kendaraan memiliki kubikasi $7746900 \mathrm{~cm} 3$.

Diagram alir menggunakan metode nearest neighbor. Nilai $\mathrm{v}$ merupakan awal dari nilai kendaraan pertama yang akan digunakan. Kemudian nilai t merupakan perjalanan awal. Lalu pada setiap kendaraan dimulai dari gudang proses selanjutnya pilih toko paling terdekat dengan lokasi awal. Pada awal pencarian lokasi dimulai dari gudang. Hitung total kapasitas toko yang sudah terpilih nilai tidak boleh melebihi total maksimal kendaraan yang digunakan. Jika kapasitas kendaraan masih dapat menampung kapasitas maka ubah nilai lokasi awal dengan toko yang terpilih. Dan jika total kapasitas kendaraan sudah tidak dapat menampung kapasitas toko maka ubah sebagai pencarian baru. Terakhir jika sudah tidak terdapat toko yang harus dilayani maka hentikan pencarian rute berakhir. 
PETIR: Jurnal Pengkajian dan Penerapan Teknik Informatika Vol. 13, No. 1, Maret 2020, P-ISSN 1978-9262, E-ISSN 2655-5018 DOI: https://doi.org/10.33322/petir.v13i1.869

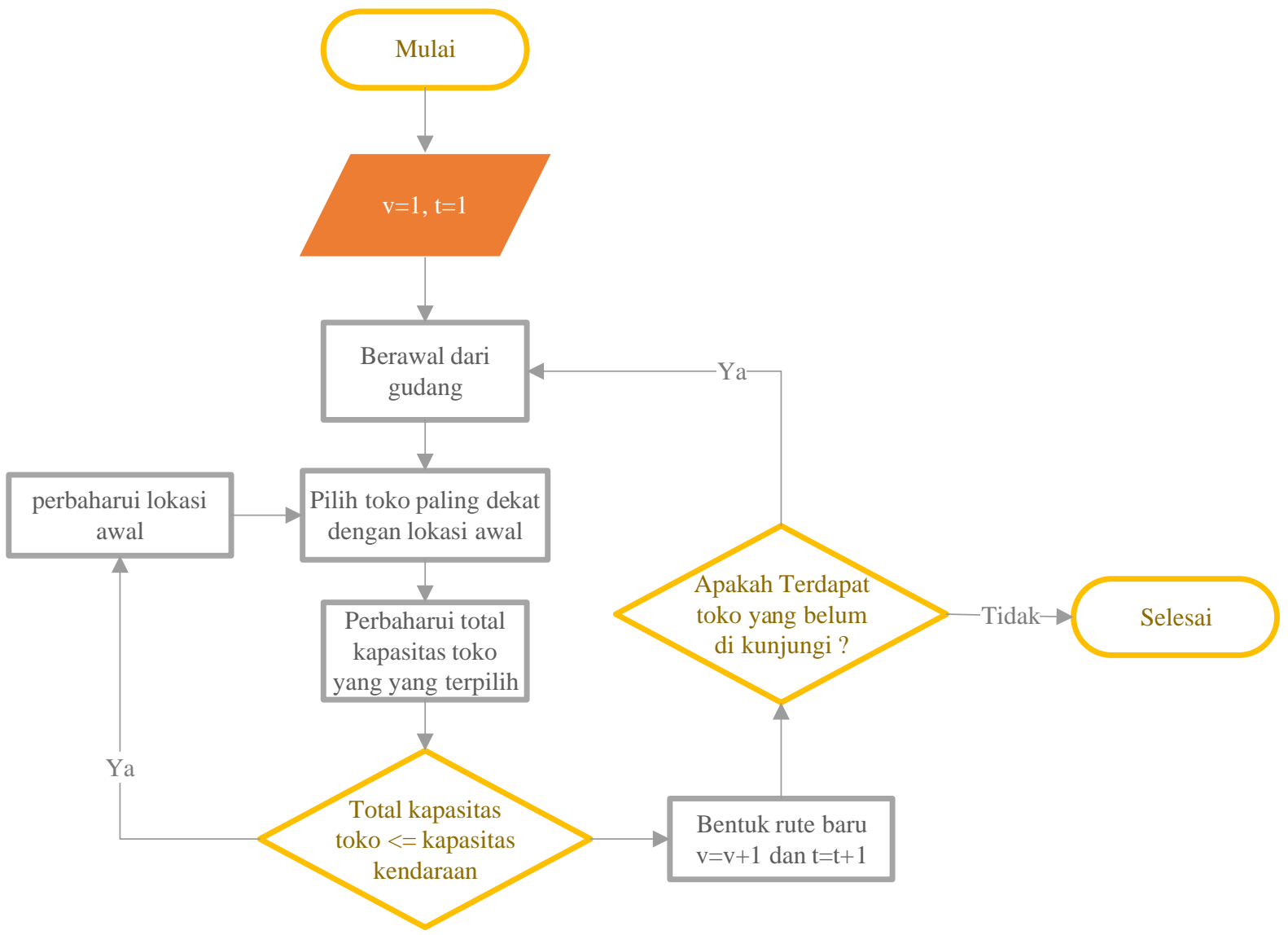

Gambar 2. Diagram alir penentuan rute

Berikut merupakan perhitungan penentuan rute di PT Sumber Alfaria Trijaya Tbk. untuk pengiriman barang dengan menggunakan metode nearest neighbor sebagai berikut. Iterasi pertama perjalanan dimulai dari gudang dan mencari tujuan pengiriman barang yang paling dekat. Telihat pada tabel 3 toko terdekat dari gudang adalah toko A1 yang kemudian diubah menjadi lokasi awal.

Tabel 3. Perhitungan rute dari gudang

\begin{tabular}{|c|c|c|r|r|r|r|l|}
\hline $\begin{array}{c}\text { Lokasi } \\
\text { Awal }\end{array}$ & $\begin{array}{c}\text { Total } \\
\text { Permintaan } \\
\text { Barang Awal } \\
\left(\mathbf{c m}^{\mathbf{3}} \mathbf{)}\right.\end{array}$ & $\begin{array}{c}\text { Lokasi } \\
\text { Tujuan }\end{array}$ & $\begin{array}{c}\text { Permintaan } \\
\text { Barang } \\
\text { tujuan } \\
\left(\mathbf{c m}^{\mathbf{3}}\right)\end{array}$ & $\begin{array}{c}\text { Jarak } \\
(\mathbf{m})\end{array}$ & $\begin{array}{c}\text { Total Permintaan } \\
\text { Barang Awal + } \\
\text { lokasi Tujuan } \\
\left(\mathbf{c m}^{\mathbf{3}}\right)\end{array}$ & $\begin{array}{c}\text { Maksimal } \\
\text { Kubikasi } \\
\text { Kendaraan } \\
\left(\mathbf{c m}^{\mathbf{3}}\right)\end{array}$ & $\begin{array}{c}\text { Cek Tidak } \\
\text { Melebihi } \\
\text { Kubikasi } \\
\text { Kendaraan }\end{array}$ \\
\hline Gudang & 0 & A2 & 1464162 & 7053 & 1464162 & 7746900 & Ya \\
\hline Gudang & 0 & A3 & 2483022 & 8171 & 2483022 & 7746900 & Ya \\
\hline Gudang & 0 & A4 & 1715579 & 8874 & 1715579 & 7746900 & Ya \\
\hline Gudang & 0 & A5 & 1235448 & 10073 & 1235448 & 7746900 & Ya \\
\hline Gudang & 0 & A6 & 2760407 & 13151 & 2760407 & 7746900 & Ya \\
\hline Gudang & 0 & A7 & 2243232 & 12830 & 2243232 & 7746900 & Ya \\
\hline Gudang & 0 & A8 & 2022624 & 12355 & 2022624 & 7746900 & Ya \\
\hline Gudang & 0 & A9 & 2490933 & 6407 & 2490933 & 7746900 & Ya \\
\hline Gudang & 0 & A10 & 1893731 & 10349 & 1893731 & 7746900 & Ya \\
\hline Gudang & 0 & A11 & 1522152 & 9679 & 1522152 & 7746900 & Ya \\
\hline Gudang & 0 & A12 & 2997580 & 12335 & 2997580 & 7746900 & Ya \\
\hline Gudang & 0 & A13 & 1433460 & 12681 & 1433460 & 7746900 & Ya \\
\hline Gudang & 0 & A1 & 1682658 & 3501 & 1682658 & 7746900 & Ya \\
\hline
\end{tabular}


PETIR: Jurnal Pengkajian dan Penerapan Teknik Informatika

Iterasi kedua dilakukan pencarian toko terdekat yang terlihat pada tabel 4. Iterasi dimulai dari gudang menuju toko A1 kemudian dilakukan pencarian dengan jarak paling terdekat terdekat. Sebelumnya pencarian dimulai dilakukan pengecekan untuk total kubikasi pada calon toko terdekat tidak melebihi kendaraan.

Tabel 1. Perhitugan rute iterasi ke dua

\begin{tabular}{|c|c|c|c|c|c|c|c|}
\hline Lokasi Awal & $\begin{array}{c}\text { Total } \\
\text { Permintaan } \\
\text { Barang Awal } \\
\left(\mathbf{c m}^{3}\right)\end{array}$ & $\begin{array}{l}\text { Lokasi } \\
\text { Tujuan }\end{array}$ & $\begin{array}{l}\text { Permintaan } \\
\text { Barang } \\
\text { tujuan }\left(\mathrm{cm}^{3}\right)\end{array}$ & $\begin{array}{c}\text { Jarak } \\
\text { (m) }\end{array}$ & $\begin{array}{c}\text { Total } \\
\text { Permintaan } \\
\text { Barang } \\
\text { Awal + } \\
\text { lokasi } \\
\text { Tujuan } \\
\left(\mathbf{c m}^{3}\right)\end{array}$ & $\begin{array}{c}\text { Maksimal } \\
\text { Kubikasi } \\
\text { Kendaraan } \\
\left(\mathrm{cm}^{3}\right)\end{array}$ & $\begin{array}{c}\text { Cek Tidak } \\
\text { Melebihi } \\
\text { Kubikasi } \\
\text { Kendaraan }\end{array}$ \\
\hline Gudang, A1 & 1682658 & A2 & 1464162 & 3551 & 3146820 & 7746900 & Ya \\
\hline Gudang, A1 & 1682658 & A3 & 2483022 & 4670 & 4165680 & 7746900 & Ya \\
\hline Gudang, A1 & 1682658 & A4 & 1715579 & 5373 & 3398237 & 7746900 & Ya \\
\hline Gudang, A1 & 1682658 & A5 & 1235448 & 6572 & 2918106 & 7746900 & Ya \\
\hline Gudang, A1 & 1682658 & A6 & 2760407 & 9650 & 4443065 & 7746900 & $\mathrm{Ya}$ \\
\hline Gudang, A1 & 1682658 & A7 & 2243232 & 9329 & 3925890 & 7746900 & $\mathrm{Ya}$ \\
\hline Gudang, A1 & 1682658 & A8 & 2022624 & 8853 & 3705282 & 7746900 & Ya \\
\hline Gudang, A1 & 1682658 & A9 & 2490933 & 2906 & 4173591 & 7746900 & Ya \\
\hline Gudang, A1 & 1682658 & A10 & 1893731 & 6848 & 3576389 & 7746900 & $\mathrm{Ya}$ \\
\hline Gudang, A1 & 1682658 & A11 & 1522152 & 6178 & 3204810 & 7746900 & $\mathrm{Ya}$ \\
\hline Gudang, A1 & 1682658 & A12 & 2997580 & 8833 & 4680238 & 7746900 & Ya \\
\hline Gudang, A1 & 1682658 & A13 & 1433460 & 7971 & 3116118 & 7746900 & $\mathrm{Ya}$ \\
\hline
\end{tabular}

Iterasi ketiga pada pencarian rute toko terdekat yaitu dimulai dari gudang kemudaian menuju toko A1 dan A9 kemudaian dilakukan pengecekan kembali pada setiap toko yang akan terpilih tidak melebihi kubikasi kendaraan. Terlihat pada tabel 5 toko A2 sebagai toko terdekat.

Tabel 2. Perhitungan iterasi ketiga

\begin{tabular}{|c|c|c|c|c|c|c|c|}
\hline Lokasi Awal & $\begin{array}{c}\text { Total } \\
\text { Permintaan } \\
\text { Barang Awal } \\
\left(\mathbf{c m}^{\mathbf{3}}\right)\end{array}$ & $\begin{array}{l}\text { Lokasi } \\
\text { Tujuan }\end{array}$ & $\begin{array}{c}\text { Permintaan } \\
\text { Barang } \\
\text { tujuan } \\
\left(\mathrm{cm}^{3}\right)\end{array}$ & $\begin{array}{c}\text { Jarak } \\
(\mathbf{m})\end{array}$ & $\begin{array}{c}\text { Total } \\
\text { Permintaan } \\
\text { Barang } \\
\text { Awal + } \\
\text { lokasi } \\
\text { Tujuan } \\
\left(\mathrm{cm}^{3}\right)\end{array}$ & $\begin{array}{c}\text { Maksimal } \\
\text { Kubikase } \\
\text { Kendaraan } \\
\left(\mathbf{c m}^{3}\right)\end{array}$ & $\begin{array}{c}\text { Cek Tidak } \\
\text { Melebihi } \\
\text { Kubikasi } \\
\text { Kendaraan }\end{array}$ \\
\hline Gudang, A1, A9 & 4173591 & $\mathrm{~A} 2$ & 1464162 & 645 & 5637753 & 7746900 & $\mathrm{Ya}$ \\
\hline Gudang, A1, A9 & 4173591 & A3 & 2483022 & 1764 & 6656613 & 7746900 & $\mathrm{Ya}$ \\
\hline Gudang, A1, A9 & 4173591 & A4 & 1715579 & 2467 & 5889170 & 7746900 & $\mathrm{Ya}$ \\
\hline Gudang, A1, A9 & 4173591 & A5 & 1235448 & 3666 & 5409039 & 7746900 & $\mathrm{Ya}$ \\
\hline Gudang, A1, A9 & 4173591 & A6 & 2760407 & 6744 & 6933998 & 7746900 & $\mathrm{Ya}$ \\
\hline Gudang, A1, A9 & 4173591 & A7 & 2243232 & 6423 & 6416823 & 7746900 & $\mathrm{Ya}$ \\
\hline Gudang, A1, A9 & 4173591 & A8 & 2022624 & 5948 & 6196215 & 7746900 & $\mathrm{Ya}$ \\
\hline Gudang, A1, A9 & 4173591 & A10 & 1893731 & 3942 & 6067322 & 7746900 & $\mathrm{Ya}$ \\
\hline Gudang, A1, A9 & 4173591 & A11 & 1522152 & 3272 & 5695743 & 7746900 & $\mathrm{Ya}$ \\
\hline Gudang, A1, A9 & 4173591 & A12 & 2997580 & 5928 & 7171171 & 7746900 & $\mathrm{Ya}$ \\
\hline Gudang, A1, A9 & 4173591 & A13 & 1433460 & 5065 & 5607051 & 7746900 & $\mathrm{Ya}$ \\
\hline
\end{tabular}


PETIR: Jurnal Pengkajian dan Penerapan Teknik Informatika

Vol. 13, No. 1, Maret 2020, P-ISSN 1978-9262, E-ISSN 2655-5018

DOI: https://doi.org/10.33322/petir.v13i1.869

Iterasi keempat toko terdekat yaitu dimulai dari gudang kemudian menuju toko A1, A9, A2 kemudian dilakukan pengecekan kembali pada setiap toko yang akan terpilih tidak melebihi kubikasi kendaraan. Terlihat pada tabel 6 toko A4 sebagai toko terdekat.

Tabel 3. Perhitungan iterasi keempat

\begin{tabular}{|l|r|r|r|r|r|r|l|}
\hline \multicolumn{1}{|c|}{ Lokasi Awal } & $\begin{array}{c}\text { Total } \\
\text { Permintaan } \\
\text { Barang } \\
\text { Awal } \\
\left(\mathbf{c m}^{\mathbf{3}}\right)\end{array}$ & $\begin{array}{c}\text { Lokasi } \\
\text { Tujuan }\end{array}$ & $\begin{array}{c}\text { Permintaan } \\
\text { Barang } \\
\text { tujuan } \\
\left(\mathbf{c m}^{3}\right)\end{array}$ & $\begin{array}{c}\text { Jarak } \\
(\mathbf{m})\end{array}$ & $\begin{array}{c}\text { Total } \\
\text { Permintaan } \\
\text { Barang Awal } \\
\mathbf{+} \text { lokasi } \\
\left.\text { Tujuan } \mathbf{( c m}^{\mathbf{3}}\right)\end{array}$ & $\begin{array}{c}\text { Maksimal } \\
\text { Kubikasi } \\
\text { Kendaraan } \\
\left(\mathbf{c m}^{3}\right)\end{array}$ & $\begin{array}{c}\text { Cek Tidak } \\
\text { Melebihi } \\
\text { Kubikasi } \\
\text { Kendaraan }\end{array}$ \\
\hline $\begin{array}{l}\text { Gudang, A1, } \\
\text { A9, A2 }\end{array}$ & 5637753 & A3 & 2483022 & 1764 & 8120775 & 7746900 & Tidak \\
\hline $\begin{array}{l}\text { Gudang, A1, } \\
\text { A9, A2 }\end{array}$ & 5637753 & A4 & 1715579 & 2467 & 7353332 & 7746900 & Ya \\
\hline $\begin{array}{l}\text { Gudang, A1, } \\
\text { A9, A2 }\end{array}$ & 5637753 & A5 & 1235448 & 3666 & 6873201 & 7746900 & Ya \\
\hline $\begin{array}{l}\text { Gudang, A1, } \\
\text { A9, A2 }\end{array}$ & 5637753 & A6 & 2760407 & 6744 & 8398160 & 7746900 & Tidak \\
\hline $\begin{array}{l}\text { Gudang, A1, } \\
\text { A9, A2 }\end{array}$ & 5637753 & A7 & 2243232 & 6423 & 7880985 & 7746900 & Tidak \\
\hline $\begin{array}{l}\text { Gudang, A1, } \\
\text { A9, A2 }\end{array}$ & 5637753 & A8 & 2022624 & 5948 & 7660377 & 7746900 & Ya \\
\hline $\begin{array}{l}\text { Gudang, A1, } \\
\text { A9, A2 }\end{array}$ & 5637753 & A10 & 1893731 & 3942 & 7531484 & 7746900 & Ya \\
\hline $\begin{array}{l}\text { Gudang, A1, } \\
\text { A9, A2 }\end{array}$ & 5637753 & A11 & 1522152 & 3272 & 7159905 & 7746900 & Ya \\
\hline $\begin{array}{l}\text { Gudang, A1, } \\
\text { A9, A2 }\end{array}$ & 5637753 & A12 & 2997580 & 5928 & 8635333 & 7746900 & Tidak \\
\hline $\begin{array}{l}\text { Gudang, A1, } \\
\text { A9, A2 }\end{array}$ & 5637753 & A13 & 1433460 & 5065 & 7071213 & 7746900 & Ya \\
\hline
\end{tabular}

Pada tabel 7 iterasi kelima sudah saat dilakukan pengecekan sudah tidak ada toko yang akan terpilih sebagai perjalanan selanjutnya. Beban pada kendaraan pada setiap calon tujuan pengiriman sudah tidak dapat lagi dimuat oleh barang karena maksimal kubikasi pada kendaraan hanya $7746900 \mathrm{~cm}^{3}$. Setelah itu membentuk perjalanan pada satu kendaraan kemudi perhitungan dilakukan kembali perhitungan yang dimulai dari gudang.

Tabel 4. Iterasi kelima

\begin{tabular}{|l|r|r|r|r|r|r|r|}
\hline \multicolumn{1}{|c|}{ Lokasi Awal } & $\begin{array}{c}\text { Total } \\
\text { Permintaan } \\
\text { Barang Awal } \\
\left(\mathbf{c m}^{\mathbf{3}}\right)\end{array}$ & $\begin{array}{c}\text { Lokasi } \\
\text { Tujuan }\end{array}$ & $\begin{array}{c}\text { Permintaan } \\
\text { Barang } \\
\text { tujuan }\left(\mathbf{c m}^{\mathbf{3}}\right)\end{array}$ & $\begin{array}{c}\text { Jarak } \\
(\mathbf{m})\end{array}$ & $\begin{array}{c}\text { Total } \\
\text { Permintaan } \\
\text { Barang Awal } \\
\mathbf{+} \text { lokasi } \\
\text { Tujuan }\left(\mathbf{c m}^{\mathbf{3}}\right)\end{array}$ & $\begin{array}{c}\text { Maksimal } \\
\text { Kubikase } \\
\text { Kendaraan } \\
\left(\mathbf{c m}^{\mathbf{3}}\right)\end{array}$ & $\begin{array}{c}\text { Cek Tidak } \\
\text { Melebihi } \\
\text { Kubikasi } \\
\text { Kendaraan }\end{array}$ \\
\hline $\begin{array}{l}\text { Gudang, A1, A9, } \\
\text { A2, A4 }\end{array}$ & 7353332 & A3 & 2483022 & 704 & 9836354 & 7746900 & Tidak \\
\hline $\begin{array}{l}\text { Gudang, A1, A9, } \\
\text { A2, A4 }\end{array}$ & 7353332 & A5 & 1235448 & 3839 & 8588780 & 7746900 & Tidak \\
\hline $\begin{array}{l}\text { Gudang, A1, A9, } \\
\text { A2, A4 }\end{array}$ & 7353332 & A6 & 2760407 & 4277 & 10113739 & 7746900 & Tidak \\
\hline $\begin{array}{l}\text { Gudang, A1, A9, } \\
\text { A2, A4 }\end{array}$ & 7353332 & A7 & 2243232 & 3956 & 9596564 & 7746900 & Tidak \\
\hline $\begin{array}{l}\text { Gudang, A1, A9, } \\
\text { A2, A4 }\end{array}$ & 7353332 & A8 & 2022624 & 3480 & 9375956 & 7746900 & Tidak \\
\hline
\end{tabular}


PETIR: Jurnal Pengkajian dan Penerapan Teknik Informatika Vol. 13, No. 1, Maret 2020, P-ISSN 1978-9262, E-ISSN 2655-5018 DOI: https://doi.org/10.33322/petir.v13i1.869

\begin{tabular}{|l|r|r|r|r|r|r|l|} 
Gudang, A1, A9, & & & & \\
A2, A4 & 7353332 & A10 & 1893731 & 1475 & 9247063 & 7746900 & Tidak \\
\hline $\begin{array}{l}\text { Gudang, A1, A9, } \\
\text { A2, A4 }\end{array}$ & 7353332 & A11 & 1522152 & 805 & 8875484 & 7746900 & Tidak \\
\hline $\begin{array}{l}\text { Gudang, A1, A9, } \\
\text { A2, A4 }\end{array}$ & 7353332 & A12 & 2997580 & 3460 & 10350912 & 7746900 & Tidak \\
\hline $\begin{array}{l}\text { Gudang, A1, A9, } \\
\text { A2, A4 }\end{array}$ & 7353332 & A13 & 1433460 & 2598 & 8786792 & 7746900 & Tidak \\
\hline
\end{tabular}

Tabel 5. Hasil perhitungan dengan metode NN

\begin{tabular}{|c|l|r|r|}
\hline No & \multicolumn{1}{|c|}{ Toko } & Kubikasi $\left(\mathbf{c m}^{\mathbf{3}}\right)$ & Total Jarak $(\mathbf{m})$ \\
\hline 1 & A1, A9, A2, A4 & 7353332 & 17748 \\
\hline 2 & A3, A11, A10, A13 & 7332365 & 25411 \\
\hline 3 & A5, A12, A8 & 6255652 & 28904 \\
\hline 4 & A7, A6 & 5003639 & 26547 \\
\hline \multicolumn{2}{|l}{ Total Jarak } & 98610 \\
\hline
\end{tabular}

Tabel 8 hasil dari algoritma nearest neighbor terbentuk 4 perjalanan atau rute dari permitaan pada toko dan tidak melebihi dari beban kendaraan. Pada rute pertama terbentuk toko A1, A9, A2, A4 yang memiliki jumlah kukikasi $7353332 \mathrm{~cm} 3$. Rute kedua A1, A9, A2, A4 denga Kubikasi 7353332, rute ketiga A5, A12, A8 kubikasi 6255652. A7, A6 kubikasi 5003639. Hasil pencarian rute menggunakan metode nearest neighbor menghasilkan jumlah rute paling sedikit dibandingkan dengan sebelum menggunakan metode dan pada total jarak dengan menggunakan metode 98610 meter atau 98,61 km sedangkan jika pada rute sebelum mengunakan metode 124198 meter atau $124,198 \mathrm{~km}$ terjadi pengurangan jarak 25588 atau 25,588 atau sebesar $20.6026 \%$.

\section{KESIMPULAN DAN SARAN}

Diperoleh penentuan rute pengiriman barang dengan metode nearest neighbor. Jumlah rute paling sedikit dibandingkan dengan sebelum menggunakan metode dan pada total jarak dengan menggunakan metode 98610 meter atau 98,61 km sedangkan jika pada rute sebelum mengunakan metode 124198 meter atau $124,198 \mathrm{~km}$ terjadi pengurangan jarak 25588 atau 25,588 atau sebesar $20.6026 \%$. nearest neighbor metode heuristik dapat digunakan untuk pemecahan masalah sebagai dasar untuk penentuan rute. Metode ini dapat digunakan untuk membatu untuk menentukan rute pengiriman sehingga resiko penumpukan barang dan penurunan penjualan barang ke konsumen menjadi berkurang.

\section{DAFTAR PUSTAKA}

[1] Xu, Rui, Guo, Rui, and Jia, Qiong. (2019). A Novel Hybrid Metaheuristic for Solving Automobile Part Delivery Logistics with Clustering Customer Distribution. IEEE Access. (Vol. 7, pp. 106075-106091). https://doi.org/10.1109/ACCESS.2019.2931622.

[2] Li, Yan, Tan, Wenru, and Sha, Ruili. (2016). The empirical study on the optimal distribution route of minimum carbon footprint of the retail industry. J. Clean. Prod. (Vol. 112, pp. 42374246). https://doi.org/10.1016/j.jclepro.2015.05.104.

[3] Belver, M., Gomez, A., Lopez, J., De la Fuente, D., and Ponte, B. (2017). Solving vehicle routing problem with multiple trips using iterative local search with variable neighborhood 
search. 2017 World Congr. Comput. Sci. Comput. Eng. Appl. Comput. CSCE 2017 - Proc. 2017 Int. Conf. Artif. Intell. ICAI 2017. (pp. 286-290).

[4] Ltifi, Moez, and Gharbi, Jameleddine. (2015). The Effect of Logistics Performance in Retail Store on the Happiness and Satisfaction of Consumers. Procedia Econ. Financ. (Vol. 23, pp. 1347-1353). https://doi.org/10.1016/s2212-5671(15)00516-x.

[5] Rehana, Shaik, Subbaiah, K Venkata, Premsai, M, Student, M, and Student, M. (2017). Solving A Capacitated Vehicle Routing Problem Using Metaheuristic Algorithm. (pp. 804808).

[6] Kim, Sungwoo, and Moon, Ilkyeong. (2019). Traveling salesman problem with a drone station. IEEE Trans. Syst. Man, Cybern. Syst. (Vol. 49, pp. 42-52). https://doi.org/10.1109/TSMC.2018.2867496.

[7] Alemayehu, Temesgen Seyoum, and Kim, Jai Hoon. (2017). Efficient Nearest Neighbor Heuristic TSP Algorithms for Reducing Data Acquisition Latency of UAV Relay WSN. Wirel. Pers. Commun. (Vol. 95, pp. 3271-3285). https://doi.org/10.1007/s11277-017-3994-9.

[8] Arora, Khushboo, Agarwal, Samiksha, and Tanwar, Rohit. (2016). Solving TSP using Genetic Algorithm and Nearest Neighbour Algorithm and their Comparison. Int. J. Sci. Eng. Res. (Vol. 7, pp. 1014-1018).

[9] Hermawan, Fahmi. (2018). Optimization Of Transportation of Municipal Solid Waste from Resource to Intermediate Treatment Facility with Nearest Neighbour Method (Study on six Sub Sub District in DKI Jakarta Province). J. Environ. Sci. Sustain. Dev. (Vol. 1, pp. 86-99). https://doi.org/10.7454/jessd.v1i1.21.

[10] Prasetyo, Waluyo et al. (2017). Vehicle Routing Problem Dengan Aplikasi Metode Nearest Neihbor. (Vol. 3, pp. 88-89).

[11] Daanish, Abdur Rahman, and Naick, B. Krishna. (2017). Implementation of charging station based electric vehicle routing problem using nearest neighbour search algorithm. 2017 2nd IEEE Int. Conf. Intell. Transp. Eng. ICITE 2017. (pp. 52-56). https://doi.org/10.1109/ICITE.2017.8056880.

[12] Joshi, Sourabh, and Kaur, Sarabjit. (2015). Nearest Neighbor Insertion Algorithm for solving capacitated vehicle routing problem. 2015 Int. Conf. Comput. Sustain. Glob. Dev. INDIACom 2015. (pp. 86-88).

[13] Dantzig, G. B., and Ramser, J. H. (1959). The Truck Dispatching Problem. Manage. Sci. (Vol. 6, pp. 80-91). https://doi.org/10.1287/mnsc.6.1.80.

[14] Taracena Sanz, Fernando, and Escobar Gómez, Elías Neftalí. (2013). The Vehicle Routing Problem With Limited Vehicle Capacities. Int. J. Traffic Transp. Eng. (Vol. 3, pp. 260-268). https://doi.org/10.7708/ijtte.2013.3(3).03.

[15] Zheng, Weimin, Liao, Zhixue, and Qin, Jing. (2017). Using a four-step heuristic algorithm to design personalized day tour route within a tourist attraction. Tour. Manag. (Vol. 62, pp. 335349). https://doi.org/10.1016/j.tourman.2017.05.006.

[16] Khan, Ajaz Ahmed. (2016). A Comparitive Study Of Nearest Neighbour Algorithm And Genetic Algorithm In Solving Travelling Salesman Problem. (Vol. 03, pp. 234-238).

[17] Neighbor, Nearest, Leymena, Leonard, W, Cahyo Suryo B, and Sutopo, Wahyudi. (2019). Analisis Penentuan Rute Distribusi Menggunakan Metode. Semin. dan Konf. Nas. IDEC. (p. E14.1-E14.7).

[18] Gottlieb, Lee Ad, Kontorovich, Aryeh, and Nisnevitch, Pinhas. (2018). Near-Optimal Sample Compression for Nearest Neighbors. IEEE Trans. Inf. Theory. (Vol. 64, pp. 4120-4128). https://doi.org/10.1109/TIT.2018.2822267. 
PETIR: Jurnal Pengkajian dan Penerapan Teknik Informatika Vol. 13, No. 1, Maret 2020, P-ISSN 1978-9262, E-ISSN 2655-5018 DOI: https://doi.org/10.33322/petir.v13i1.869

[19] Solomon, Marius M. (1987). Algorithms for the Vehicle Routing and Scheduling Problems With Time Window Constraints. Oper. Res. (Vol. 35, pp. 254-265). https://doi.org/10.1287/opre.35.2.254.

[20] Pop, Petrica Claudiu, Zelina, Ioana, Lupse, Vasile, Sitar, Corina Pop, and Chira, Camelia. (2011). Heuristic algorithms for solving the generalized vehicle routing problem. Int. J. Comput. Commun. Control. (Vol. 6, pp. 158-165). https://doi.org/10.15837/ijccc.2011.1.2210. 
PETIR: Jurnal Pengkajian dan Penerapan Teknik Informatika Vol. 13, No. 1, Maret 2020, P-ISSN 1978-9262, E-ISSN 2655-5018

DOI: https://doi.org/10.33322/petir.v13i1.869

\section{LAMPIRAN}

1. Data permintaan barang.

\begin{tabular}{|c|l|l|l|}
\hline No & Kode Toko & Nama Toko & Kubikasi $\left.\mathbf{( c m}^{\mathbf{3}}\right)$ \\
\hline 1 & A1 & TOKO 1 & 1682658 \\
\hline 2 & A2 & TOKO 2 & 1464162 \\
\hline 3 & A3 & TOKO 3 & 2483022 \\
\hline 4 & A $~$ & TOKO 4 & 2483022 \\
\hline 5 & A5 & TOKO 5 & 2243232 \\
\hline 6 & A6 & TOKO 6 & 1893731 \\
\hline 7 & A7 & TOKO 7 & 2243232 \\
\hline 8 & A8 & TOKO 8 & 2022624 \\
\hline 9 & A9 & TOKO 9 & 2490933 \\
\hline 10 & A10 & TOKO 10 & 1893731 \\
\hline 11 & A11 & TOKO 11 & 1522152 \\
\hline 12 & A12 & TOKO 12 13 & 2997580 \\
\hline 13 & A13 & TOKO 13 & 1433460 \\
\hline
\end{tabular}

\section{Data hasil rute sebelum menggunakan metode NN}

\begin{tabular}{|c|l|l|l|}
\hline No & Toko & Kubikasi $\left(\mathbf{c m}^{3}\right)$ & Total Jarak $(\mathbf{m})$ \\
\hline 1 & A1, A6 & 4443065 & 26455 \\
\hline 2 & A3, A5, A10 & 5612201 & 26346 \\
\hline 3 & A2, A4, A9 & 5670674 & 17749 \\
\hline 4 & A7, A12, A13 & 6674272 & 28926 \\
\hline 5 & A8, A11 & 3544776 & 24722 \\
\hline \multicolumn{2}{|l}{} & 124198 \\
\hline
\end{tabular}


PETIR: Jurnal Pengkajian dan Penerapan Teknik Informatika Vol. 13, No. 1, Maret 2020, P-ISSN 1978-9262, E-ISSN 2655-5018 DOI: https://doi.org/10.33322/petir.v13i1.869

\section{Matriks jarak}

\begin{tabular}{|c|c|c|c|c|c|c|c|c|c|c|c|c|c|c|}
\hline & 1MZ1 & A2 & A3 & A4 & A5 & A6 & A7 & A8 & A9 & A10 & A11 & A12 & A13 & A1 \\
\hline 1MZ1 & 0 & 7053 & 8171 & 8874 & 10073 & 13304 & 12974 & 12367 & 6407 & 10349 & 9679 & 12347 & 12681 & 3501 \\
\hline A2 & 7053 & 0 & 1118 & 1822 & 2866 & 6251 & 5922 & 5315 & 645 & 3297 & 2627 & 5295 & 4432 & 3551 \\
\hline $\mathbf{A 3}$ & 8171 & 1118 & 0 & 704 & 4542 & 5133 & 4804 & 4197 & 1764 & 2179 & 1509 & 4177 & 3314 & 4670 \\
\hline A4 & 8874 & 1822 & 704 & 0 & 3839 & 4429 & 4100 & 3493 & 2467 & 1475 & 805 & 3473 & 2611 & 5373 \\
\hline A5 & 10073 & 3072 & 4542 & 3839 & 0 & 6562 & 6101 & 5626 & 3666 & 3297 & 3033 & 5606 & 4744 & 6572 \\
\hline A6 & 13151 & 6099 & 4981 & 4277 & 6410 & 0 & 413 & 964 & 6744 & 4046 & 3472 & 1795 & 2205 & 9650 \\
\hline A7 & 12830 & 5778 & 4659 & 3956 & 6089 & 406 & 0 & 1359 & 6423 & 3725 & 3151 & 2190 & 2600 & 9329 \\
\hline A8 & 12355 & 5302 & 4184 & 3480 & 5626 & 964 & 1336 & 0 & 5948 & 3262 & 2675 & 858 & 1268 & 8853 \\
\hline A9 & 6407 & 645 & 1764 & 2467 & 3666 & 6897 & 6567 & 5960 & 0 & 3942 & 3272 & 5940 & 5078 & 2906 \\
\hline $\mathbf{A 1 0}$ & 10349 & 3297 & 2179 & 1475 & 3284 & 4199 & 3737 & 3262 & 3942 & 0 & 670 & 3242 & 2380 & 6848 \\
\hline A11 & 9679 & 2627 & 1509 & 805 & 3033 & 3624 & 3295 & 2688 & 3272 & 670 & 0 & 2668 & 1805 & 6178 \\
\hline A12 & 12335 & 5282 & 4164 & 3460 & 5606 & 1795 & 2167 & 858 & 5928 & 3242 & 2655 & 0 & 1248 & 8833 \\
\hline A13 & 12681 & 4420 & 3302 & 2598 & 4744 & 2205 & 2577 & 1268 & 5065 & 2380 & 1793 & 1248 & 0 & 7971 \\
\hline A1 & 3501 & 3551 & 4670 & 5373 & 6572 & 9802 & 9473 & 8866 & 2906 & 6848 & 6178 & 8846 & 7984 & 0 \\
\hline
\end{tabular}

